\title{
Folk taxonomy of fishes of artisanal fishermen of Ilhabela (São Paulo/Brazil)
}

\author{
Milena Ramires ${ }^{1,2,4}$, Mariana Clauzet ${ }^{1,2}$ \& Alpina Begossi ${ }^{1,2,3}$ \\ ${ }^{1}$ Programa de Pós-graduação em Sustentabilidade de Ecossistemas Costeiros e Marinhos - ECOMAR, \\ Universidade Santa Cecília - UNISANTA, Rua Cesário Mota, 24, Boqueirão, \\ CEP 11045-040, Santos, SP, Brasil \\ ${ }^{2}$ Fisheries and Food Institute - FIFO, Rua Cesário Mota, 24, Boqueirão, \\ CEP 11045-040, Santos, SP, Brasil \\ ${ }^{3}$ Laboratório de Capacitação de Pescadores Artesanais para o Manejo da Pesca-CAPESCA/, \\ Pró-Reitoria de Extensão e Assuntos Comunitários - PREAC, Centro de Memória UNICAMP - CMU, \\ Universidade Estadual de Campinas - UNICAMP, CP 6023, \\ CEP 13083-970, Campinas, SP, Brasil \\ ${ }^{4}$ Corresponding author: Milena Ramires, e-mail: milena@unisanta.br
}

RAMIRES, M., CLAUZET, M. \& BEGOSSI, A. Folk taxonomy of fishes of artisanal fishermen of Ilhabela (São Paulo/Brazil). Biota Neotrop. 12(4): http://www.biotaneotropica.org.br/v12n4/en/abstract?article+bn00412042012

\begin{abstract}
This article investigates the folk taxonomy of four artisanal fisheries communities in Ilhabela/SP. The local folk taxonomy shows how these fishermen identify, name and classify fish resources in the environment exploited by them. Forty-two fishermen from four different local communities of Ilhabela were interviewed through a structured questionnaire and photographs of fish species with occurrence for the southeast region of Brazil. Respondents identified the 24 species listed as 50 generic names and 27 binominal specific names, mainly related to aspects of fish species morphology such as color, shape and size. These fish were classified into eight groups according to local criteria related to the morphology, ecology and fishing forms associated with the capture of species. The morphological aspect was identified as the most used feature by respondents to name and classify local fish, followed by ecological aspects such as behavior, diet and habitat. The comparison of local criteria used for the groups was similar to the scientific taxonomy criteria, showing a detailed local ecological knowledge by this group of fishers.

Keywords: ichthyofauna, biodiversity, biological classification, human ecology, ethnoecology, fisheries resources.
\end{abstract}

RAMIRES, M., CLAUZET, M. \& BEGOSSI, A. Etnotaxonomia de peixes dos pescadores artesanais de Ilhabela (São Paulo/Brasil). Biota Neotrop. 12(4): http://www.biotaneotropica.org.br/v12n4/pt/ abstract?article+bn00412042012

Resumo: Este artigo investiga a etnotaxonomia de quatro comunidades de pescadores artesanais de Ilhabela/SP. A etnotaxonomia mostra como esses pescadores, identificam, nomeam e classificam os recursos pesqueiros no ambiente explorado por eles. Quarenta e dois pescadores de quatro diferentes comunidades locais de Ilhabela foram entrevistados através de um questionário estruturado e fotografias de espécies de peixes de ocorrência para a região sudeste do Brasil. Os entrevistados identificaram as 24 espécies listadas através de 50 nomes genéricos e 27 nomes específicos binomiais, principalmente relacionados com aspectos morfológicos como forma, cor e tamanho. Estes peixes foram classificados em oito grupos de acordo com critérios locais relacionados com a morfologia, ecologia e técnicas de pesca associados à captura de tais espécies. O aspecto morfológico foi identificado como o fator mais utilizado pelos entrevistados para nomear e classificar as espécies de peixes, seguidos por critérios relacionados à ecologia das espécies tais como, dieta, comportamento e habitat. A comparação dos critérios locais utilizados para os grupos foi semelhante aos critérios científicos de taxonomia, mostrando um detalhado conhecimento ecológico local deste grupo de pescadores.

Palavras-chave: ictiofauna, biodiversidade, classificação biológica, ecologia humana, etnoecologia, recursos pesqueiros. 


\section{Introduction}

Artisanal fishing is an important economic activity in rural or native communities which often include broad systems of knowledge about the fish existing in the environments exploited. Berlin (1992), based on studies of ethnobiology, emphasizes that local communities dominate the three steps of systematic detail when folk ecological knowledge about identification, naming and classification of local species. When investigated these steps show the classification system popular in the studied community that may be similar in different environments, reflecting the universal principles of classification of nature in different cultures (Marques 1991, Berlin 1992).

The interactions of human populations with nature can be investigated through the study of fishing practices and use of marine resources from the perspective of ethnoicthiology that, according to Marques (1991), is the branch of ethnobiology that specifically addresses the interactions between humans and fish. In this interaction, human populations establish their criteria for identification and naming of natural resources they use, forming their own rating systems of nature, which can be investigated through studies of folk biology. Local knowledge of human populations on nature has various denominations in the literature such as: "indigenous knowledge", "local ecological knowledge-LEK", "traditional ecological knowledge-TEK" or "folk knowledge" (Posey 1986, Berlin 1992, Berkes \& Folke 1998, Berkes 1999, Begossi 2004, Drew 2005).

It is considered appropriate in this article using the terminology "local ecological knowledge" to deal with the knowledge of local fishermen about the nature and the folk taxonomic term to speak of local knowledge expressed by fishermen on the nomenclature and classification of fish.

The local ecological knowledge is itself a cultural context in a given environment. Learning this kind of knowledge takes place, overall, by direct observation of natural phenomena and experience from the activity of natural resources exploitation. According to Diegues (1995), local knowledge about nature is a set of knowledge and know-how. From this perspective, studying human populations' knowledge about the natural world is to understand the relationship between knowledge and action of local populations ahead the natural resources exploited and managed by them.

Studies comparing the classical and folk taxonomies, describing the criteria used by both for classifying organisms, have being developed especially in recent decades and reveal principles of organization and classification of nature in different cultures (Berlin 1992, Faulkner \& Silvano 2003). Among these studies, we can mention Marques $(1991,2001)$ in estuarine-lagoon complex MundaúManguaba (Alagoas); Begossi \& Garavello (1990) in the Tocantins River (Amazon); Begossi \& Figueiredo (1995) in Búzios Island (SP) and Sepetiba Bay (RJ); Paz \& Begossi (1996) in the Bay of Sepetiba (RJ), Costa Neto \& Marques (2000) with fishermen of Siribinha (BA); Seixas \& Begossi (2001) on the Ilha Grande, Coastal southeastern Brazil; Mourão \& Nordi (2002a, b) in the estuary Mamanguape (PB); Clauzet et al. (2007) in Guaibim (BA) and Begossi et al. (2008) on the Atlantic coast of Brazil and Amazon.

The local ecological knowledge comprises many ecological, behavioral and classification of fish species that implies in how fishermen manage fisheries resources. Overall, the knowledge acquired by fishing communities is deep and rich in details, often consistent with scientific observations. The plurality of knowledge permeating the practices of fish populations can contribute to the construction of scientific knowledge and strategies for conservation of natural resources based on new local information for biological research. Silvano \& Valbo-Jorgensen (2008) propose hypothesis testing of local ecological knowledge in order to be added to scientific knowledge, when local knowledge is compatible ("high-probability hypothesis") to the existing scientific research, or even when indicates new directions for the same.

The comparison between the two forms of knowledge and the importance of the sum of local ecological knowledge to scientific knowledge for the conservation of social and ecological resources of environment are highlighted in the works of Acheson (1988), Johannes (2002) and Ruddle \& Hickey (2008), among others.

Other approaches relate the local ecological knowledge and use of natural resources to management ways and conservation. Lopes et al. (2011a, b), for example, show how is possible using ecological models as tool to understand the use of natural resources and behavior of human populations and, in an even broader context, the article of Begossi et al. (2011) is the interface between human ecology and economic ecology, discussing economic and technical alternatives to co-management for artisanal fishermen in areas of environmental protection and industrial fisheries, considering the success of initiatives of payment for environmental services (PES) in forest areas and fisheries agreements (FAs) in the Brazilian Amazon.

This study aimed at conducting a study on the local folk taxonomy focused on the identification and classification of fish by fishermen who know and use marine resources in their traditional fishing practices in the region of Ilhabela/SP.

\section{Materials and Methods}

Ilhabela is a archipelagic municipality of 12 small islands, two slabs and the inhabited islands of São Sebastião, Búzios and Vitoria. It is located on the northern coast of São Paulo, $220 \mathrm{~km}$ from the capital (São Paulo). According to the IBGE Census (Instituto... 2011), the population of Ilhabela municipality is 28,196 inhabitants. The city has some special features about geography and biological richness, source of livelihood for those who live from its fauna and flora and for those who exploit the tourism (Merlo 2000, Maldonado 2004).

The São Sebastião Island is the largest island in the municipality, $348 \mathrm{~km}^{2}$ and has its face towards the São Sebastião channel, an urbanized area with characteristics common to a small town: small industries, commerce, services and concentration a greater number of inhabitants. It is also the area where tourism is developed, with large numbers of vacation residences, hotels, hostels, campsites, etc. (Maldonado 1997, Calvente 1997). It is covered for the most part by the hillside rainforest, the Atlantic Forest, with plenty of small watersheds in steep relief, with more than 400 streams rapids, features that give it a great tourist potential (Calvente 1997).

In the municipality of Ilhabela is located the Ilhabela State Park, created in 1977 with 27,025 hectares, covering about 80\% of the municipal area. The park covers much of the São Sebastião Island, whose limits are defined by altitudes $(100 \mathrm{~m}$ and $200 \mathrm{~m})$ and marine areas, including small islands and slabs that make up the archipelago (Maldonado 1997).

Native families remaining in the most urbanized part of the São Sebastião Island have their lives transformed by changes from the technical progress and cultural values assimilated through tourism and media. Other communities still live in relative isolation in some beaches distant from the central region of the island. So-called "isolated communities" are so considered by the urban population due to the precariousness of access, either by land or sea, in relation to the urban center.

In this research we conducted interviews on folk taxonomy with artisanal fishermen from beaches Bonete, Fome, Jabaquara and Serraria. The beach Jabaquara (north of Ilhabela) is connected by land road of difficult transportation to the urban center; Bonete (to the south), linked by roads that in the last $9 \mathrm{~km}$ become in trail of 
difficult access; Praia da Fome and Praia da Serraria are accessible only by sea (Figure 1).

We analyzed the fishermen who developed fishing activity for 10 years or more. Fishermen were interviewed using questionnaires and photographic material. This material consisted of a kit, consisting of photos of 24 fish species, which often represent the main species present in the composition of fish caught by fishermen from the north coast of São Paulo. Fish species that were part of the kit had already been pre-determined by the researchers since this research was part of a major research project in the area coordinated by one of the authors (AB). Fish pictures used in this project were done by R. A. M. Silvano, from FIFO and UFRGS, Porto Alegre, Brazil and was described in Begossi et al. (2008). In this technique, already used successfully in previous studies (Marques 1991, Paz \& Begossi
1996, Silvano 2001, Silvano \& Begossi 2002, Silvano et al. 2006), fish photographs were given to fishermen in the same order for all respondents, being it determined by draw. While viewing photos, fishermen answered the following questions: 1) What is this fish? 2) What is its name? 3) Which of these fish are relatives or in the same family? 4) What is a relative? Subsequently, fisherman was asked to group the photos according to his knowledge of the "kinship" of fish.

Data were analyzed qualitatively and quantitatively. Seeking to represent the consensus among informants interviewed, responses were analyzed as a percentage of quotes about every aspect addressed. Most of the answers or the most frequently mentioned aspects were considered as most relevant information on the local ecological knowledge (Paz \& Begossi 1996, Silvano \& Begossi 2005). The local information was compared with the scientific literature on compared

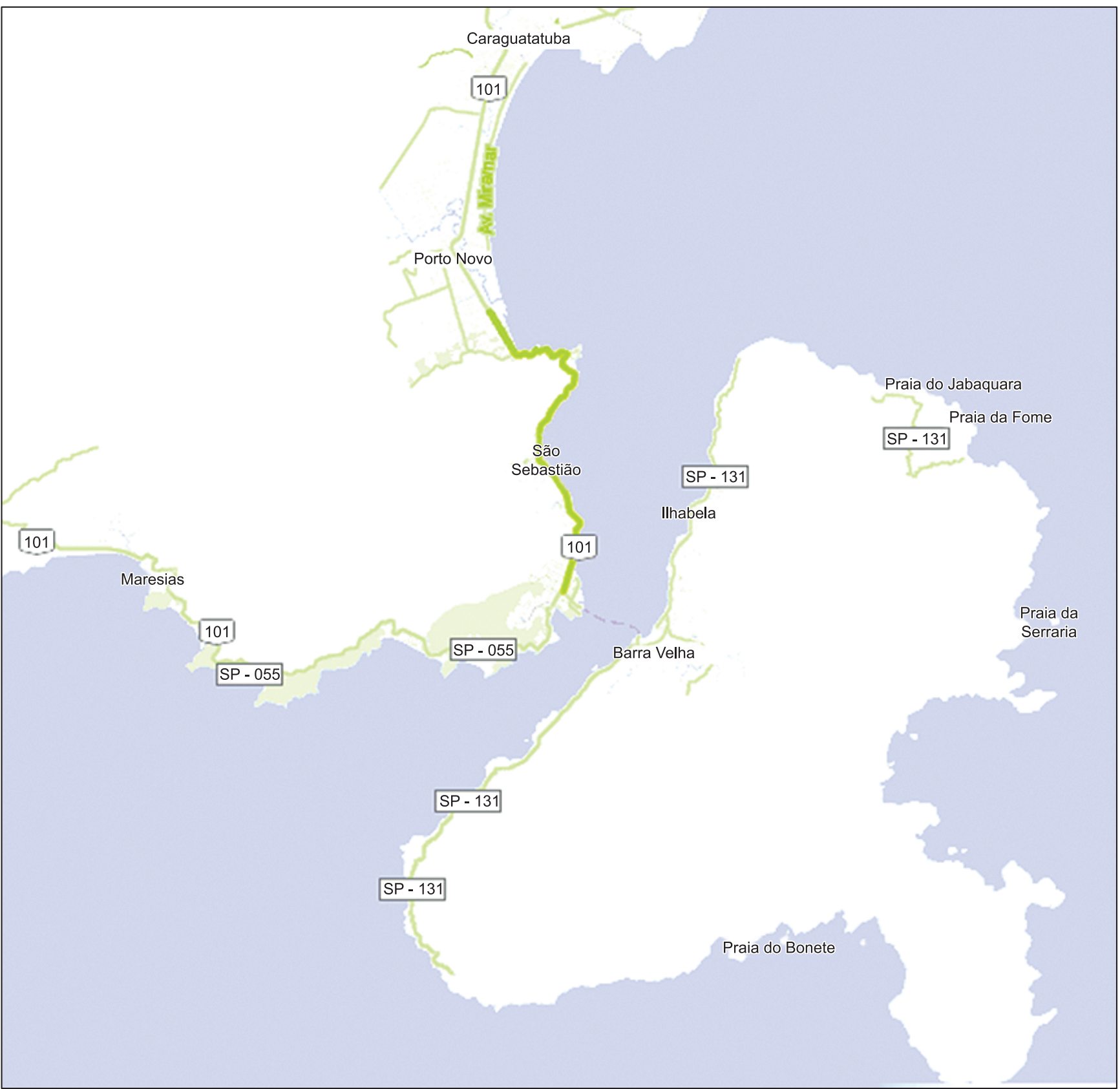

Figure 1. Communities of fishermen studied in the Ilhabela/SP. 
cognition tables, according to Marques (1991), through literature reviews on fish species addressed in this research and discussed with the theoretical framework of folk systematic, especially developed in the work of Berlin (1992). Data on folk taxonomy detailed in this article have been shown more widely in the study of Begossi et al. (2008) who made a comparison between taxonomy of fishers from southeast of Sao Paulo and Amazon; therefore, the results of data analysis collected in Ilhabela can be understood as a deepening of the analysis performed earlier by these authors.

\section{Results and Discussion}

The twenty-four species presented to the fishermen belong to19 genera and 11 families. The nomenclature of fishermen for fish species mostly was carried out by generic names and for some fish has been given binominal names, resulting in 50 generic names and 27 binominal specific names (Table 1).

Most of species was named by fishermen with monotypic generic names, the main ones: corvina/Micropogonias furnieri

Table 1. Fish Nomenclature according to the fishermen of Ilhabela. Values correspond to the number of citations in interviews ( $\mathrm{N}=42$ fishermen interviewed).

\begin{tabular}{|c|c|c|c|c|c|c|c|}
\hline $\begin{array}{c}\text { Fish scientific } \\
\text { name }\end{array}$ & $\begin{array}{l}\text { Generic } \\
\text { name }\end{array}$ & $\mathbf{N}$ & $\%$ & Binominal & $\mathbf{N}$ & $\%$ & $\begin{array}{c}\text { Non-recognized } \\
\text { fish }\end{array}$ \\
\hline \multirow{4}{*}{ 1. Bodianus rufus (Linnaeus, 1758) } & godião & 22 & 52.4 & godião-batata & 8 & 19 & 5 \\
\hline & caranha & 1 & 2.4 & godião-fogueira & 1 & 2.4 & \\
\hline & vermelho & 1 & 2.4 & godião-papagaio & 3 & 7.1 & \\
\hline & & & & vermelho-caranha & 1 & 2.4 & \\
\hline \multirow{3}{*}{ 2. Epinephelus marginatus (Lowe, 1834) } & garoupa & 39 & 92.8 & garoupa-legitima & 1 & 2.4 & 0 \\
\hline & & & & garoupa-preta & 1 & 2.4 & \\
\hline & & & & garoupa-São-Tomé & 1 & 2.4 & \\
\hline \multirow[t]{4}{*}{ 3. Epinephelus morio (Valenciennes, 1828) } & garoupa & 8 & 19 & garoupa-São-Tomé & 18 & 42.8 & 1 \\
\hline & badejo & 6 & 14.3 & garoupa-banana & 8 & 19 & \\
\hline & & & & garoupa-legitima & 1 & 2.4 & \\
\hline & & & & garoupa-vermelha & 1 & 2.4 & \\
\hline \multirow[t]{4}{*}{ 4. Caranx latus Agassiz, 1831} & xaréu & 35 & 83.3 & xaréu-olhudo & 1 & 2.4 & 1 \\
\hline & xarelete & 1 & 2.4 & xaréu-cacundo & 1 & 2.4 & \\
\hline & piranga & 1 & 2.4 & & & & \\
\hline & betara & 1 & 2.4 & & & & \\
\hline \multirow[t]{5}{*}{ 5. Umbrina coroides Cuvier, 1830} & betara & 30 & 71.4 & corvina-da-areia & 5 & 11.9 & 0 \\
\hline & corvina & 5 & 11.9 & & & & \\
\hline & maria-luisa & 3 & 7.1 & & & & \\
\hline & badejo & 1 & 2.4 & & & & \\
\hline & xarelete & 1 & 2.4 & & & & \\
\hline \multirow[t]{6}{*}{ 6. Mycteroperca bonaci (Poey, 1860) } & badejo & 23 & 54.8 & badejo-branco & 1 & 2.4 & 1 \\
\hline & miracelo & 13 & 33.3 & & & & \\
\hline & badejote & 2 & 4.8 & & & & \\
\hline & água-fria & 1 & 2.4 & & & & \\
\hline & badejinho & 1 & 2.4 & & & & \\
\hline & cherne & 1 & 2.4 & & & & \\
\hline \multirow[t]{2}{*}{ 7. Mugil curema Valenciennes, 1836} & parati & 31 & 73.8 & parati-guaçú & 1 & 2.4 & 0 \\
\hline & tainha & 11 & 26.2 & & & & \\
\hline \multirow[t]{2}{*}{ 8. Seriola lalandi Valenciennes, 1833) } & olhete & 32 & 76.2 & olhete-verde & 3 & 7.1 & 0 \\
\hline & olho-de-boi & 8 & 19 & & & & \\
\hline \multirow[t]{4}{*}{ 9. Bodianus pulchellus (Poey, 1860) } & godião & 19 & 45.2 & godião-fogueira & 6 & 14.3 & 3 \\
\hline & vermelho & 2 & 4.8 & godião-batata & 4 & 9.5 & \\
\hline & sabonete & 2 & 4.8 & godião-vermelho & 4 & 9.5 & \\
\hline & trilha & 1 & 2.4 & godião-papagaio & 1 & 2.4 & \\
\hline \multirow[t]{2}{*}{ 10. Oligoplites saliens (Bloch, 1793) } & guaivira & 40 & 95.2 & & & & 0 \\
\hline & salteira & 2 & 4.8 & & & & \\
\hline 11. Pomatomus saltatrix (Linnaeus, 1766) & anchova & 42 & 100 & & & & 0 \\
\hline \multirow[t]{2}{*}{ 12. Caranx crysos (Mitchill, 1815) } & carapau & 23 & 54.8 & xaréu-amarelo & 2 & 4.8 & 0 \\
\hline & xarelete & 20 & 46.6 & & & & \\
\hline 13. Micropogonias furnieri (Desmarest, 1823) & corvina & 42 & 100 & & & & \\
\hline \multirow{5}{*}{$\begin{array}{l}\text { 14. Cynoscion jamaicensis (Vaillant \& Bocourt, } \\
\text { 1883) }\end{array}$} & goete & 29 & 69 & goete-da-pedra & 1 & 2.4 & 3 \\
\hline & pescada & 3 & 7.1 & goete-cascudo & 1 & 2.4 & \\
\hline & maria-mole & 2 & 4.8 & pescada-branca & 1 & 2.4 & \\
\hline & betara & 1 & 2.4 & pescada-cascuda & 1 & 2.4 & \\
\hline & robalo & 1 & 2.4 & & & & \\
\hline
\end{tabular}


Table 1. Continued...

\begin{tabular}{|c|c|c|c|c|c|c|c|}
\hline $\begin{array}{c}\text { Fish scientific } \\
\text { name } \\
\end{array}$ & $\begin{array}{c}\text { Generic } \\
\text { name }\end{array}$ & $\mathbf{N}$ & $\%$ & Binominal & $\mathbf{N}$ & $\%$ & $\begin{array}{c}\text { Non-recognized } \\
\text { fish }\end{array}$ \\
\hline \multirow[t]{7}{*}{ 15. Stegastes fuscus (Cuvier, 1830) } & café-torrado & 20 & 46.6 & & & & 8 \\
\hline & tiniuna & 12 & 28.6 & & & & \\
\hline & corintiano & 1 & 2.4 & & & & \\
\hline & paru & 1 & 2.4 & & & & \\
\hline & peixe-frade & 1 & 2.4 & & & & \\
\hline & sargo & 1 & 2.4 & & & & \\
\hline & gudião & 1 & 2.4 & & & & \\
\hline \multirow{6}{*}{$\begin{array}{l}\text { 16. Scomberomorus brasiliensis Collette, Russo } \\
\text { \& Zavala-Camin }\end{array}$} & sororoca & 25 & 59.5 & cavalinha-do-norte & 2 & 4.8 & 0 \\
\hline & cavala & 11 & 26.2 & & & & \\
\hline & olhete & 1 & 2.4 & & & & \\
\hline & olho-de-boi & 1 & 2.4 & & & & \\
\hline & olhudo & 1 & 2.4 & & & & \\
\hline & robalo & 1 & 2.4 & & & & \\
\hline 17. Centropomus parallelus Poey, 1860 & robalo & 41 & 98 & & & & 1 \\
\hline \multirow[t]{2}{*}{ 18. Mycteroperca acutirostris (Valenciennes, 188) } & miracelo & 29 & 69 & & & & 0 \\
\hline & badejo & 14 & 33.3 & & & & \\
\hline \multirow[t]{4}{*}{ 19. Abudefduf saxatilis (Linnaeus, 1758) } & tiniuna & 39 & 92.8 & & & & 1 \\
\hline & corintiano & 5 & 11.9 & & & & \\
\hline & paulistinha & 3 & 7.1 & & & & \\
\hline & porquinho & 1 & 2.4 & & & & \\
\hline \multirow[t]{3}{*}{ 20. Euthynnus alleteratus (Rafinesque, 1810) } & bonito & 34 & 80.9 & bonito-pintado & 4 & 9.5 & 0 \\
\hline & olhete & 1 & 2.4 & bonito-pulador & 2 & 4.8 & \\
\hline & bacoria & 1 & 2.4 & & & & \\
\hline 21. Trichiurus lepturus Linnaeus, 1758 & espada & 42 & 100 & & & & 0 \\
\hline \multirow[t]{2}{*}{ 22. Mugil platanus Gunther, 1880} & tainha & 33 & 78.6 & & & & 0 \\
\hline & parati & 11 & 26.2 & & & & \\
\hline \multirow[t]{5}{*}{ 23. Menticirrhus americanus (Linnaeus, 1758) } & betara & 22 & 52.4 & betara-roliça & 5 & 11.9 & 2 \\
\hline & perna-de-moça & 13 & 30.9 & betara-preta & 1 & 2.4 & \\
\hline & pau-de-fumo & 5 & 11.9 & & & & \\
\hline & papa-terra & 1 & 2.4 & & & & \\
\hline & maria-luiza & 1 & 2.4 & & & & \\
\hline \multirow[t]{3}{*}{ 24. Lutjanus synagris (Linnaeus, 1758) } & vermelho & 30 & 71.4 & vermelho-cioba & 6 & 14.3 & 2 \\
\hline & corcoroca & 3 & 7.1 & & & & \\
\hline & pargo & 1 & 2.4 & & & & \\
\hline Totais: & 50 & - & & 27 & - & & - \\
\hline
\end{tabular}

(Desmarest, 1823), anchova/Pomatomus saltatrix (Linnaeus, 1766) and espada/Trichiurus lepturus Linnaeus, 1758, which were called for $100 \%$ of fishermen and showed no specific associated, as well as the robalo/Centropomus parallelus Poey, 1860 cited by $98 \%$ of fishermen. According to Berlin (1992) names that represent the generic taxa are always more numerous in any folk classification system and can be divided into monotypic and polytypic. When the generic taxon is the terminal hierarchical level perceived by fishermen, it is called monotypic.

Among the monotypic generic names mentioned by fishermen of Ilhabela, 19 of them were also presented by Freire \& Carvalho Filho (2009). This work the authors present an important assessment of the richness of Brazilian common names for reef and reef-associated fish species, and provide an initial list of unique common names for species studied.

Clauzet et al. (2007) conducted a study on folk taxonomy in Guaibim/BA, using 21 fish species common to this work and found a variety of generic names even greater than this study, being cited 122 generic and only 16 binomial names. The emphasis on generic names found between fishermen of Ilhabela/SP and Guaibim/BA has also been demonstrated by Begossi \& Figueiredo (1995), who found about 20\% binomial names among fishermen from Búzios Island (SP) and Sepetiba Bay (RJ) and Seixas \& Begossi (2001) at Ilha Grande (RJ), who found 97 generic and 25 binomial names for 123 scientific species. According to Berlin (1992), semantic terms as simple as monotypic generic names found in Ilhabela could be related to ease of learning language among human populations.

In addition to monotypic names, polytypic generic names (or binomial) were also mentioned which, according to Berlin (1992), are those subdivided into specific and invariably refer to those classes of culturally important organisms. The polytypic most frequently cited were: garoupa-são-tomé/Epinephelus morio (Valenciennes, 1828), 42.8\%; garoupa-banana/Epinephelus morio (Valenciennes, 1828), 19\%; godião-batata/Bodianus rufus (Linnaeus, 1758), 19\% and Bodianus pulchellus (Poey, 1860), 9.5\%; godião-fogueira/Bodianus pulchellus (Poey, 1860), 14.3\%, vermelho-cioba/Lutjanus synagris (Linnaeus, 1758), 14.3\% and corvina-da-areia/Umbrina coroides Cuvier, 1830, 11.9\% respectively related to the monotypic: garoupa, godião, vermelho and corvina.

Mourão \& Nordi (2002a) conducted a review of Brazilian ethnoichtyological works by checking the proportionality monotypic/ polytypic existing in naming species and found that the same generic polytypic may represent one or more species. According to these authors, the specific folk taxa recorded in studies on folk taxonomy 
are fewer than those on generic, which was also observed in the nomenclature of fishermen of Ilhabela (SP), generic monotypic were majority.

Among the generic names, fishermen of Ilhabela identify fish by simple generic (Peroá, betara, etc) and compound names (eg, peixeporco, peixe-folha, peixe-gato). Some of most frequently generic compound names cited were: café-torrado/Stegastes fuscus (Cuvier, 1830), 46.6\%; perna-de-moça/Menticirrhus americanus (Linnaeus, 1758), 30.9\%; olho-de-boi/Seriola lalandi Valenciennes, 1833, 19\%; pau-de-fumo/Menticirrhus americanus (Linnaeus, 1758), 11.9\% and Maria-Luisa/Umbrina coroides Cuvier, 1830, 7.1\%.

The binomiality is given in the case of generic modifiers, ie, when some generic name is added of a supplement name that makes it specific. Among the binomial cited by fishermen of Ilhabela, it was possible to identified references to as morphological such as color (godião-fogueira, garoupa-preta, garoupa-vermelha, badejobranco, godião-vermelho, xaréu-amarelo, bonito-pintado and betara-preta) and format (xaréu-olhudo) ecological aspects such as habitat (corvina-da-areia, goete-da-pedra e cavalinha-do-norte) and analogies with terrestrial organisms (godião-batata e godiãopapagaio). Among the fishermen of the River Estuary Mamanguape (PA), Mourão \& Nordi (2002a) found that the popular nomenclature of some fish results from analogies made in relation to domestic animals or objects. Some examples include: peixe-gato, peixe-galo and peixe-agulha, among others; however, they are not characterized as a binomial, but as compound generic names.

According to Berlin (1992), organisms categorized into generic taxa are identified by several morphological marked and distinguishable features. However, organisms included in specific categories require a more detailed observation of the morphological aspects. Living organisms of generic taxa are usually included in the category of life forms such as fish, trees etc. For Brown (1984), "life forms" are sets of living beings easily or naturally recognized in different cultures by their discontinuity in nature, generally recognized by morphological characters. From this perspective, trees are "life forms"; wherever the local knowledge about nature is investigated, organisms perceived as trees are high-rank categories, easily recognized. However, for some categories for example, "fish", other aquatic organisms are often included, such as turtles, crustaceans and dolphins. According to Mourão \& Nordi (2002a), the classification of some aquatic mammals and invertebrates into the "fish" category is due to the fact that fishermen can group these organisms not only by morphological similarities but by sharing the same habitat.

The categories of organisms perceived by human populations are related to ecological salience of these classes of organisms and may be related to certain cultural usefulness of certain organisms for the population recognizing it, or to visibly notable features. Atran (1999) emphasizes that human populations more distant from nature tend to recognize a greater number of "life forms", since under these circumstances they do not have a detailed knowledge of living beings, unlike a human population that lives in close relationship with natural resources and tends to classify them into specific ranks (specific form) and name them using binomial names. Fishermen in Ilhabela for example, named 15 of the 24 fish species studied by binomial names. Begossi et al. (2008) used the same 24 species studied in this work in fishing communities on the coast of São Paulo (Bertioga, Ilhabela and Ubatuba) and found that species were named by 27 generic and 54 binomial names, binomial proved to be related to salient features of fish such as color and shape.

The use of the binomial in fish identification by fishermen of Ilhabela may indicate the recognition of distinct categories of natural resources and especially the close relationship of human population with exploited fish stocks, strengthening the idea of closeness between man and nature to create detailed popular classification systems, as emphasized by Atran (1999).

The morphological aspect in the binomial identification of organisms is very prominent in the literature (Berlin 1992). Studies show that morphological characteristics of fish are a strong trend in the composition of popular classification systems with binomial both among fishermen in coastal communities (Begossi \& Garavello 1990, Begossi \& Figueiredo 1995, Clauzet et al. 2007) among coastal fishermen in the Brazilian Amazon (Begossi et al. 2008). In Ilhabela (SP), results of popular binomial nomenclature reinforce the importance of morphological characteristics of organisms in folk systematic showing the predominance of morphological characters in fish identification, $56 \%$ binomial names being related to some morphology aspect of named fish. The main morphological features used by fishermen of Ilhabela for fish nomenclature were: color (37\%) and shape (18.5\%).

In addition to morphology, there are also ecological criteria for binomially such as those related to the habitat of the species. Among fishermen of northeastern Brazil, Marques (1991) found in Lagoon-Estuary Complex Mundaú-Manguaba (AL) various local names in reference to usual habitats of ethnospecies of the fish family locally recognized as "Moré family" (Gobiidae and Eleontridae) as for example, Moré-de-Capim, Moré-de-Pau and Moré-de-Mangue.

Among fishermen of Ilhabela, some habitat-related criteria binomial examples include: goete-da-pedra/Cynoscion jamaicensis (Vaillant \& Bocourt, 1883) and corvina-da-areia/Umbrina coroides Cuvier, 1830. In relation to the ecological aspect of behavior, fishermen of Ilhabela identified the bonito-pulador/Euthynnus alleteratus (Rafinesque, 1810). Through association with plants were identified garoupa-banana/Epinephelus morio (Valenceinnes, 1828) and godião-batata/Bodianus rufus (Linnaeus, 1758) and Bodianus pulchellus (Poey, 1860). The godião/Bodianus rufus (Linnaeus, 1758) and Bodianus pulchellus (Poey, 1860), were also associated with other animals being identified as godião-papagaio. Binomially criteria related to the behavior and association with other animals and plants were also reported among fishermen in other regions of Brazilian coast (Begossi \& Garavello 1990, Marques 1991, Begossi \& Figueiredo 1995, Seixas \& Begossi 2001).

In studies of fish folk taxonomy, one of the key questions is whether the fishermen recognize and classify the various species in different groups and their justifications. According to Paz \& Begossi (1996) and to Begossi et al. (2008) fish can be locally recognized by fishermen as "cousins" or "relatives" and grouped into higher categories (high-ranking) locally known as "families" (folk families). Other folk taxonomy studies on different fishermen communities found the local perception of fish as relatives (Clauzet et al. 2007).

Such an approach was made to fishermen of Ilhabela from the research groups of fish that could be formed by fishermen interviewed with the 24 species used in research and the local criteria for such groups. Fishermen in Ilhabela formed eight fish groups based on local criteria that are overall similar to those of scientific taxonomy. The groups are composed of 16 species of 11 genera belonging to six biological families: Mugilidae, Labridae, Carangidae, Pomacentridae, Serranidae and Sciaenidae. The groups and comparison of local criteria to the fish taxonomy are as follows (Table 2).

In all the groups formed by the fishermen, species are of the same biological families. As for the fish identification, morphological characters are also the main reference for fishermen to form fish groups. In group $1(\mathrm{n}=33)$, cited by $78.6 \%$ fishermen and made up of Mugil curema Valenciennes, 1836 and M.platanus Gunther, 1880, (Mugilidae): the main aspect observed by fishermen to the relationship among fish was morphology, demonstrated by responses such as 


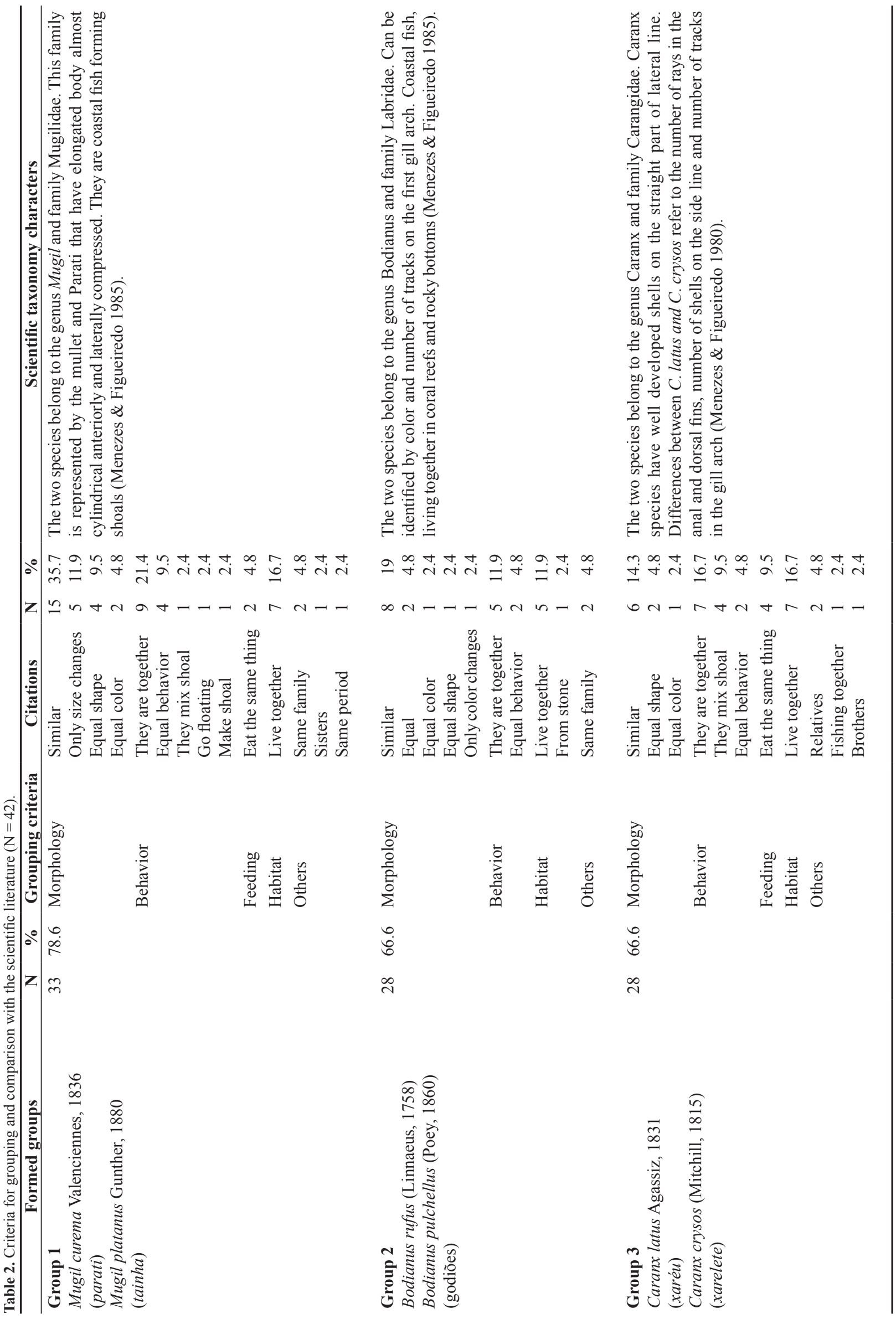


Ramires, M. et al.

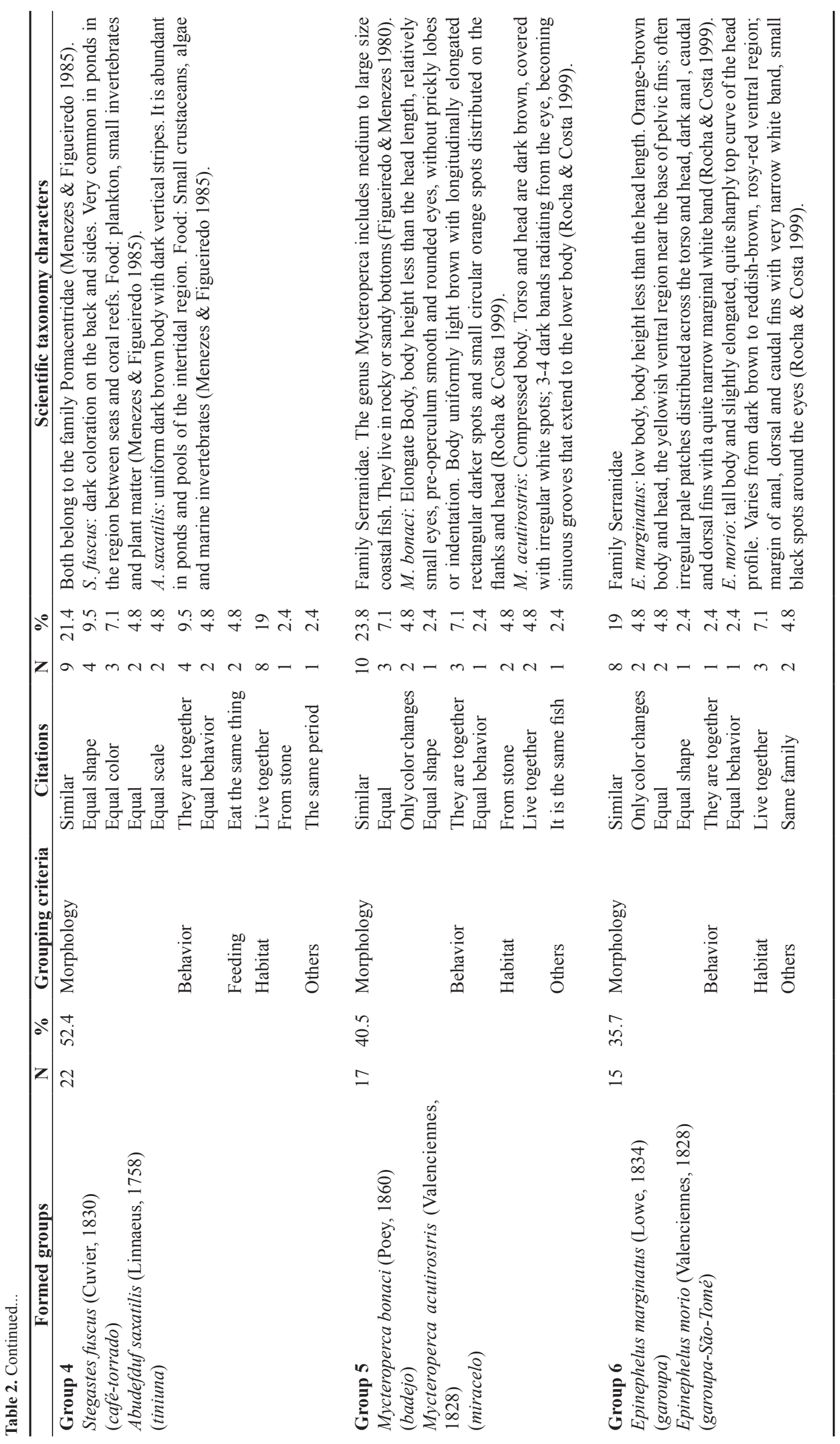




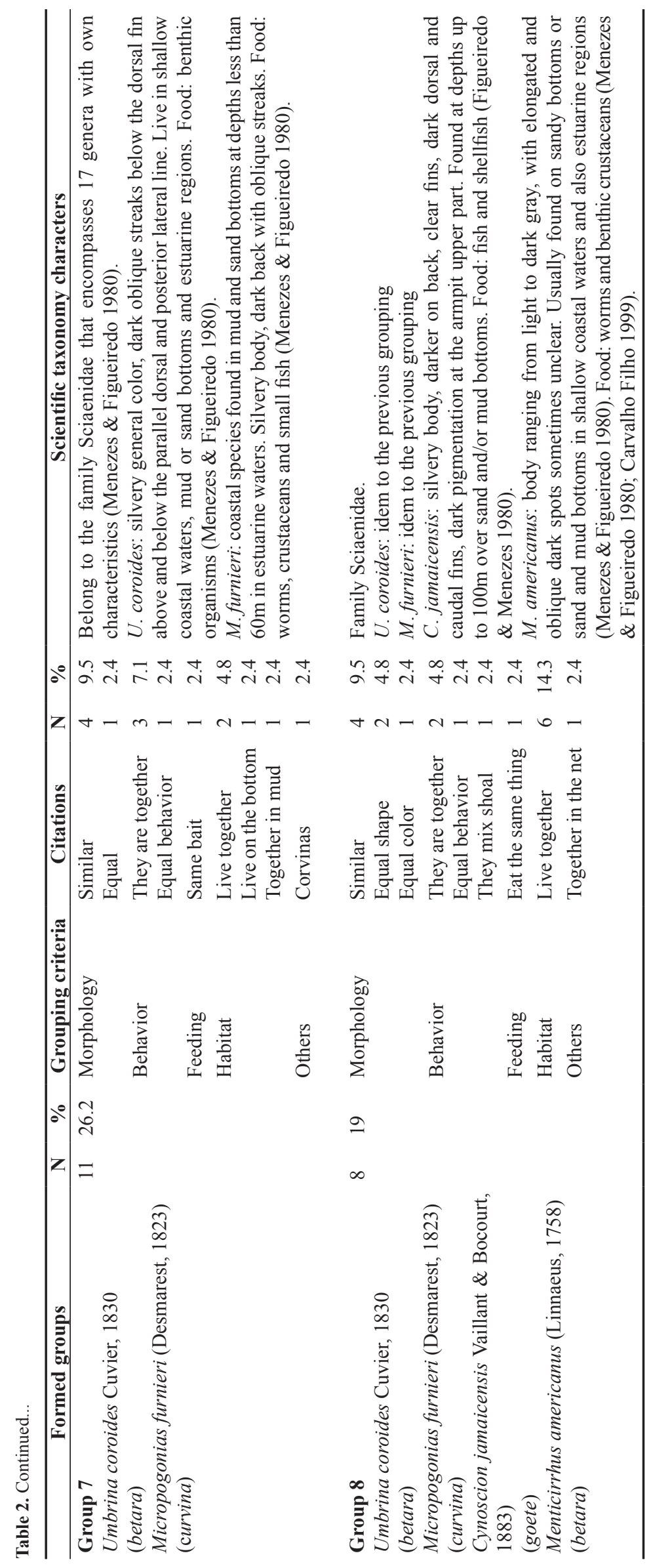


"same shape" and "same color". Group $2(66.6 \%, \mathrm{n}=28)$ formed by Bodianus rufus (Linnaeus, 1758) and B. pulchellus (Poey, 1860) (Labridae), was also identified by morphological criteria specifically related to color and shape of these fish. From comparisons between local groups formed by respondents and taxonomic literature, we can see similarities between scientific characters used for fish taxonomy and the criteria by which fishermen grouped fish. There are correspondences, for example, morphological characters of color and body shape, described to the scientific taxonomy to by fishermen to group fish revealed in responses such as, "they are similar", "they have the same color" and "they have equal shape". An example is the scientific description of the species Mugil platanus Gunther, 1880 and M. curema Valenciennes, 1836 (Mugilidae) (which were included in Group 1):

Mugilidae species were also grouped by fishermen from other regions of the Brazilian coast, being assigned to them a relationship according to local criteria of color, body shape, diet and habitat (Souza \& Barrella 2001, Clauzet et al. 2007, Begossi et al. 2008).

In addition to the importance of morphological characters in the recognition of distinct fish groups, fishermen of Ilhabela also make use of ecological (habitat and food) and behavioral criteria (shoals/fish association) for species classification within the same group. Group 2, for example, formed by Bodianus rufus (Linnaeus, 1758 ) and B. pulchellus (Poey, 1860) (Labridae) cited by $66.6 \%$ of respondents $(\mathrm{n}=28)$ was identified not only by morphological criterion (color and shape), but also behavioral and ecological criteria demonstrated in responses such as "living in the stone," "go together in the same place" among others. Such criteria were similar to those used in scientific description of such species: . Other works on folk taxonomy describe the use of ecological criteria by fishermen, for example, in Guaibim/BA where the species B.pulchelus (Poey, 1860) and B. rufus (Linnaeus, 1758) are recognized by local fishermen as fish of the same family based on the fact that they live in the same habitat (Clauzet et al. 2007). Group 3 Caranx latus Agassiz, 1831 and C. crysos (Mitchill, 1815) (Carangidae) cited by $66.6 \%$ of respondents $(n=28)$ based primarily on the fact "going together in shoal" and morphological similarities was also pointed out in studies of Clauzet et al. (2007) and Begossi et al. (2008), based on the same folk taxonomy criteria.

Mycteroperca bonaci (Poey, 1860), M. acutirostris (Valencienes, 1828), Epinephelus marginatus (Lowe, 1834) and E. morio (Valenciennes, 1828) belong to the family Serranidae (Figueiredo \& Menezes 1980). According to the fishermen of Ilhabela, these species comprise two different groups: M. bonaci (Poey, 1860) and M. acutirostris (Valencienes, 1828) in group $5(40.5 \%, \mathrm{n}=17)$ and E. marginatus (Lowe, 1834) and E. morio (Valenciennes, 1828) in group $6(35.7 \%, \mathrm{n}=15)$. The local criteria used for these two groups are related to habitat and also performed consistent with the scientific literature and previously recorded in work of Begossi et al. (2008) among fishermen from other communities on the coast of São Paulo.

The species Umbrina coroides Cuvier, 1830 and Micropogonias furnieri (Desmarest, 1823) (Sciaenidae) appeared in two different groups, being grouped by $26.2 \%$ of fishermen as unique representatives of group $7(\mathrm{n}=11)$ and by $19 \%$ of fishermen as representatives of the group $8(\mathrm{n}=8)$, which also includes the species Cynoscion jamaicensis (Vaillant \& Bocourt, 1883) and Menticirrhus americanus (Linnaeus, 1758). Even so, fishermen's grouping criteria for two groups corresponded to the taxonomic criteria found in the scientific literature and also reflect the perception of similarities among ecological aspects related to habitat and diet of such fish.

In addition to morphological, ecological and behavioral criteria observed for formation of fish groups, there was citation of criteria related to aspects of fishing activities of fishermen. For example, groups 1 (Mugil curema Valenciennes, 1836 and M. platanus Gunther, 1880, Sciaenidae) and 4 (Stegastes fuscus (Cuvier, 1830) and Abudefduf saxatilis (Linnaeus, 1758), Pomacentridae) were justified by citing "the same period." This criterion relates to the seasonality of captures of these species, which in the understanding of local fishermen makes them "relatives" and it is also a local criterion for classification as the others already mentioned: "going together", "eat the same thing" and "living together", can also be captured together at the same time.

In addition to seasonality, fishing technology is used by fishermen of Ilhabela as a criterion for fish grouping. Citations like: "fishing together," "when fishing one, fishing another" and "when one comes on the network, the other comes too", used to justify the group 3 (Carangidae): Caranx latus Agassiz, 1831 and C. crysos (Mitchill, 1815), and group 8 (Sciaenidae): Umbrina coroides Cuvier, 1830, Micropogonias furnieri (Desmarest, 1823), Cynoscion jamaicensis (Vaillant \& Bocourt, 1883) and Menticirrhus americanus (Linnaeus, 1758), demonstrate this. For fishermen, if these fish are often caught together with the same fishing technology they are considered "relatives." The capture mode as a folk taxonomy criterion suggests of local ecological knowledge about the species through the experience acquired with fishing activities.

Overall, it may be noted that fishermen of Ilhabela differentiate fish species and recognize different groups existing in nature. It is evident in the results obtained the similarity between popular and scientific classification systems. The criteria used by the fishermen from Ilhabela to recognize and identify the fish as well as to distinguish themselves in different groups are in agreement with scientific taxonomy.

\section{Conclusions}

Among the many factors that influence the local classification of fish recorded in the results, the morphological aspect is more prominent in the popular classification system of fishing communities studied in Ilhabela (SP). Overall, the results of folk taxonomy show that the morphology (shape of the head and body, color and size of fish) is the main criterion of classification in local systems surveyed. Add up the morphology, ecological criteria related to habitat and fish behavior and aspects of fishing activity, such as shooting mode, totaling the representation of popular classification system of fishermen from Ilhabela.

Finally, the recognition of fish categories based on its habitat and behavior and fishing practices that demonstrated the fishermen of Ilhabela make this local classification system a potential knowledge to be used in conservation initiatives and scientific research on fish behavior. The local ecological knowledge about behavior and habitat of species when added to that scientific can become more efficient the conservation of different species living in the same habitat and sharing similar habits in nature.

Considering the difficulty of biological studies unravel the biodiversity, both in terms of collection effort and in time spent on research and the importance of local knowledge for efficient ways of management, it can be considered that the detailed popular classification system demonstrated in this study suggests that fishermen may be included in scientific studies as having important biological and ecological information on fish, which will add in conservation planning of fisheries resources.

\section{Acknowledgements}

We thank FAPESP for the grant $n^{\circ} 01 / 05263$ - (Biota) and for providing the $\mathrm{PhD}$ scholarship process $\mathrm{n}^{\circ}$ 04/02183-6 and CAPES for the Social Demand scholarship (Process 330033017/082 Nepam/ 
UNICAMP) who helped and gave support to data collections included in this article. One of the authors (AB) thanks CNPq for the research productivity scholarship. We thank Maira Begalli for the collaboration.

\section{References}

ACHESON, J.M. 1988. The lobster gangs of maine. University Press of New England, United States of America.

ATRAN, S. 1999. Itzaj Maya folkbiological taxonomy: cognitive universal sand cultural particulars. In Folkbiology (D.L. Medin \& S. Atran, eds.). The MIT Press, Cambridge, p.119-203.

BEGOSSI, A. 2004. Introdução: ecologia humana. In Ecologia de Pescadores da Mata Atlântica e da Amazônia (A. Begossi, org.). Hucitec, São Paulo, p.13-36,

BEGOSSI, A. \& GARAVELLO, J.C. 1990. Notes on the Ethnoichthyology of Fishermen from the Tocantins River (Brazil). Acta Amazon. 20:341-351.

BEGOSSI, A. \& FIGUEIREDO, J.L. 1995. Ethnoicthyology of Southern Coastal Fishermen: Cases from Búzios Island and Sepetiba Bay (Brazil). B. Mar. Sci. 56(2):710-717.

BEGOSSI, A., CLAUZET, M., FIGUEIREDO, J.L., GARUANA, L.R.V., LIMA, P.F., MacCORD, P.F., RAMIRES, M., SILVA, A.L. \& SILVANO, R.A.M. 2008. Are biological species and higher-ranking categories real? Fish folk taxonomy on Brazil's Atlantic Forest and in the Amazon. Curr. Anthropol. 49(2):1-16. http://dx.doi.org/10.1086/527437

BEGOSSI, A., MAY, P.H., LOPES, P.F., OLIVEIRA, L.E.C., VINHA, V. \& SILVANO, R.M.A. 2011. Compensation for environmental services from artisanal fisheries in SE Brazil: Policy and technical strategies. Ecol. Econ. 71:25-32. http://dx.doi.org/10.1016/j.ecolecon.2011.09.008

BERKES, F. 1999. Sacred ecology: traditional ecological knowledge and resource management. Taylor \& Francis, Philadelphia.

BERKES, F. \& FOLKE, C. 1998. Linking social and ecological systems for resilience and sustainability. In Linking Social and Ecological Systems: management practices and social mechanisms for building resilience (F. Berkes, C. Folke, J. Colding). Cambridge University Press, p.1-25.

BERLIN, B. 1992. Ethnobiological Classification: Principles of categorization of plants and animals in tradicional societies. Princeton University Press, Princeton.

BROWN, C. 1984. Language and Living things: Uniformities in folk classification and naming. Rutgers University Press, New Brunswick.

CALVENTE, M.D.C.M.H. 1997. Ilhabela: Turismo e Território. In Ilhas e Sociedades Insulares (A.C. Diegues). NUPAUB, São Paulo, p.93-109.

CARVAlHO FILHO, A. 1999. Peixes: costa brasileira. Melro, São Paulo.

CLAUZET, M., RAMIRES, M. \& BEGOSSI, A. 2007. Etnoictiologia dos pescadores artesanais da Praia de Guaibim, Valença (BA), Brasil. Neotrop. Biol. Cons. 2(3):136-154.

COSTA-NETO, E.M. \& MARQUES, J.G.W. 2000. Etnotaxonomia de Recursos Ictiofaunísticos pelos Pescadores da Comunidade de Siribinha, Norte do Estado da Bahia, Brasil. Biociências 8(2):61-76.

DIEGUES, A.C. 1995. Povos e mares: leituras em sócio-antropologia marítima. NUPAUB/USP, São Paulo.

DREW, J.A. 2005. Use of tradicional ecological knowledge in marine conservation. Conserv. Biol. 19(4):1236-1293. http://dx.doi.org/10.1111/ j.1523-1739.2005.00158.x

FAULKNER, A. \& SILVANO, R.A.M. 2003. Status of Research on Tradicional Fishers' Knowledge in Australia and Brazil. In Putting Fishers' Knowledge to work (N. Haggan, C. Brignall \& L. Wood, eds.). Fisheries Centre Research Reports, University of British Columbia, Vancouver, v.11, n.1, p.110-116.

FIGUEIREDO, J.L. \& MENEZES, N.A. 1980. Manual de peixes marinhos do sudeste do Brasil: III. Teleostei (2). Museu de Zoologia da USP, São Paulo.
FREIRE, K.F. \& CARVALHO FILHO, A. 2009. Richness of common names of Brazilian reef fishes. PanamJAS. 4(2):96-145.

INSTITUTO BRASILEIRO DE GEOGRAFIAE ESTATÍSTICA-IBGE. 2011. Cidades@.http://www.ibge.gov.br/cidadesat/default.php. (último acesso em 15/01/2011).

JOHANNES, R.E. 2002. The renaissance of community-based marine resource management in Oceania. Annu. Rev. Ecol. Syst. 33:317-340. http://dx.doi.org/10.1146/annurev.ecolsys.33.010802.150524

LOPES, P.F.M., SILVANO, R.A.M. \& BEGOSSI, A. 2011a. Extractive and Sustainable Development Reserves in Brazil: resilient alternatives to fisheries? J. Environ. Plann. Manag. 54(4):421-443. http://dx.doi.org/10 $.1080 / 09640568.2010 .508687$

LOPES, P.F.M., CLAUZET, M., HANAZAKI, N., RAMIRES, M., SILVANO, R.A.M. \& BEGOSSI, A. 2011b. Foraging behavior of Brazilian Riverine and Coastal Fishers: How much is explained by the Optimal Foraging Theory? Conserv. Soc. 9(3):263-246. http://dx.doi.org/10.4103/09724923.86994

MALDONADO, W. 1997. Comunidades Caiçaras e o Parque Estadual de Ilhabela. In Ilhas e Sociedades Insulares (A.C. Diegues). NUPAUB, São Paulo.

MALDONADO, W. 2004. A construção material e simbólica da canoa em Ilhabela. In Enciclopédia Caiçara (A.C. Diegues, org.). NUPAUB, São Paulo, p.297-320.

MARQUES, J.G.W. 1991. Aspectos ecológicos na etnoictiologia dos pescadores do Complexo Estuarino - Lagunar Mandaú - Manguaba, Alagoas. Tese de Doutorado, Universidade Estadual de Campinas, Campinas.

MARQUES, J.G. 2001. Pescando pescadores: ciência e etnociência em uma perspectiva ecológica. NUPAUB, São Paulo.

MENEZES, N.A. \& FIGUEIREDO, J.L. 1980. Manual de peixes marinhos do sudeste do Brasil: IV. Teleostei (3). Museu de Zoologia da USP, São Paulo, 96p.

MENEZES, N.A. \& FIGUEIREDO, J.L. 1985. Manual de peixes marinhos do sudeste do Brasil: V. Teleostei (4). Museu de Zoologia da USP, São Paulo, 105p.

MERLO, M. 2000. Memória de Ilhabela: faces ocultas, vozes no ar. EDUC/ FAPESP, São Paulo.

MOURÃO, J.S. \& NORDI, N. 2002a. Principais critérios utilizados por pescadores artesanais na taxonomia Folk dos peixes do estuário do Rio Mamanguape, Paraíba-Brasil. Interciencia 27(11):607-612.

MOURÃO, J.S. \& NORDI, N. 2002b. Comparações entre as taxonomias Folk e científica para os peixes do estuário do Rio Mamanguape, ParaíbaBrasil. Interciencia 27(12):664-668.

PAZ, V. \& BEGOSSI, A. 1996. Ethnoichthyology of Gamboa Fishermen of Sepetiba Bay, Brazil. J. Ethnobiol. 16(2):157-168.

POSEY, D.A. 1986. Etnobiologia: Teoria e prática. In SUMA Etnológica Brasileira (B.G. Ribeiro). Vozes, Petrópolis, v.1 (etnobiologia), p.15-25.

ROCHA, L.O.F. \& COSTA, P.A.S. 1999. Manual de identificação de peixes marinhos para a costa central. Programa REVIZEE/SCORE - Central, São Paulo

RUDDLE, K. \& HICKEY, F.R., 2008. Accounting for the mismanagement of tropical nearshore fisheries. Environ. Dev. Sustain. 10:565-589. http:// dx.doi.org/10.1007/s10668-008-9152-5

SEIXAS, C.S. \& BEGOSSI, A. 2001. Ethnozoology of Fishing Communities From Ilha Grande (Atlantic Forest Coast, Brazil). J. Ethnobiol. 21(1):107135.

SILVANO, R.A.M. 2001. Etnoecologia e História Natural de Peixes no Atlântico (Ilha de Búzios, Brasil) e Pacífico (Moreton Bay, Austrália). Tese de Doutorado, Universidade Estadual de Campinas, Campinas.

SILVANO, R.A.M. \& BEGOSSI, A. 2002. Ethnoichthyology and Fish Conservation in the Piracicaba River (Brazil). J. Ehnobiol. 22(2):285-306. 
Ramires, M. et al.

SILVANO, R.A.M. \& BEGOSSI, A. 2005. Local knowledge on a cosmopolitan fish ethnoecology of Pomatomussaltatrix (Pomatomidae) in Brazil and Australia. Fish. Res. 71:43-59. http://dx.doi.org/10.1016/j. fishres.2004.07.007

SILVANO, R.A.M., MacCORD, P.F.L., LIMA, R.V. \& BEGOSSI, A. 2006. When does this spawn? Fishermen's local knowledge of migration and reproduction of Brazilian coastal fishes. Environ. Biol. Fish 76:371-386. http://dx.doi.org/10.1007/s10641-006-9043-2
SILVANO, R.M.A. \& VALBO-JORGENSEN, J. 2008. Beyond fishermen's tales: contribuitions of fisher's local ecological knowledge to fish ecology and fisheries management. Environ. Dev. Sustain. 10(5):657-675. http:// dx.doi.org/10.1007/s10668-008-9149-0

SOUZA, M.R. \& BARRELLA, W. 2001. Conhecimento Popular sobre Peixes numa Comunidade Caiçara da Estação Ecológica de Juréia Itatins (SP). Bol. Inst. Pesca 27(2):97-104. 